\title{
Defining Curricular Priorities for Student-as- Teacher Programs: A National Delphi Study
}

\section{Citation}

Rana, Jasmine. 2017. Defining Curricular Priorities for Student-as-Teacher Programs: A National Delphi Study. Master's thesis, Harvard Medical School.

\section{Permanent link}

http://nrs.harvard.edu/urn-3:HUL.InstRepos:42077944

\section{Terms of Use}

This article was downloaded from Harvard University's DASH repository, and is made available under the terms and conditions applicable to Other Posted Material, as set forth at http:// nrs.harvard.edu/urn-3:HUL.InstRepos:dash.current.terms-of-use\#LAA

\section{Share Your Story}

The Harvard community has made this article openly available.

Please share how this access benefits you. Submit a story.

\section{Accessibility}


This Thesis, "Defining curricular priorities of student-as-teacher programs," presented by Jasmine Rana, and Submitted to the Faculty of The Harvard Medical School in Partial Fulfillment of the Requirements for the Master of Medical Sciences in Medical Education has been read and approved by:

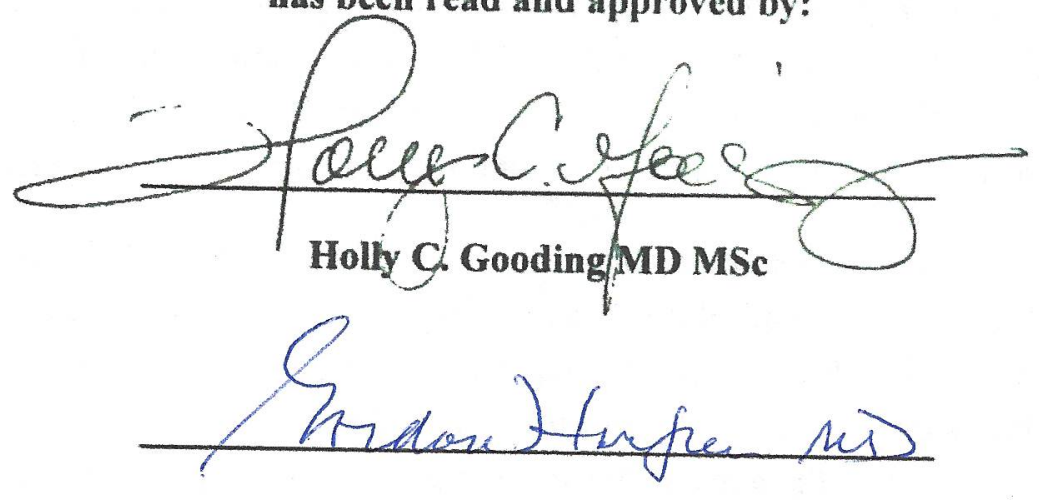

Gordon Harper MD

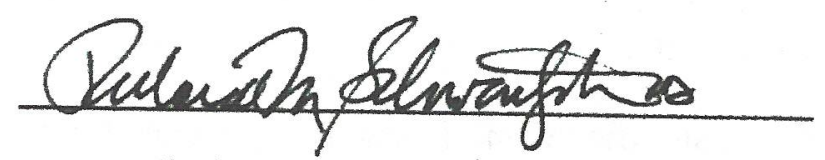

Richard M. Schwartzstein MD

Date: April 3, 2017 

DEFINING CURRICULAR PRIORITIES FOR STUDENT-AS-TEACHER PROGRAMS:

A NATIONAL DELPHI STUDY

JASMINE RANA

A Thesis Submitted to the Faculty of

The Harvard Medical School

in Partial Fulfillment of the Requirements

for the Degree of Master of Medical Sciences in Medical Education

Harvard University

Boston, Massachusetts.

May, 2017 
Defining curricular priorities for Student-as-Teacher programs: a national Delphi study

\begin{abstract}
Background: "Student-as-Teacher" (SaT) programs have been growing in number to prepare medical students for their teaching roles in residency and beyond, but it remains unknown what content areas should be covered in SaT curricula. Aim: To determine five to ten "essential" content areas for inclusion in SaT curricula using expert opinion. Methods: Using a three-round Delphi process, moderators iteratively surveyed a panel of 28 medical educators (25 academy directors and three individuals identified as having expertise in undergraduate medical education) representing 25 medical schools in the United States. This "SaT Delphi Working Group" was tasked with rating topics for inclusion in SaT curricula on a 3-point scale (i.e., 1-“essential," 2-“important, but not essential," 3-“not important"). Topics achieving $\geq 70 \%$ consensus as "essential," "important," or "not important" were accepted by the moderators and removed from subsequent rounds. Results: $100 \%$ response rate $(n=28)$ was achieved for all survey rounds. Five content areas reached consensus as "essential" for inclusion in a SaT curriculum: feedback, bedside teaching and clinical precepting, small-group teaching, case-based teaching, and professionalism as a medical educator. Conclusion: This consensus from a group of leaders in medical education is a first step toward the implementation of more developmentally-appropriate SaT competencies.
\end{abstract}




\section{Table of Contents}

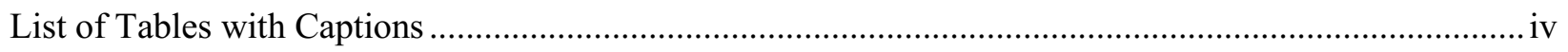

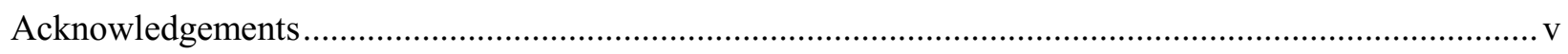

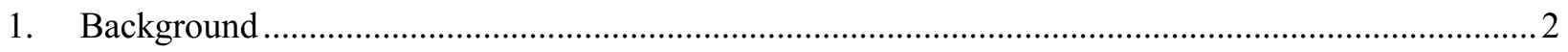

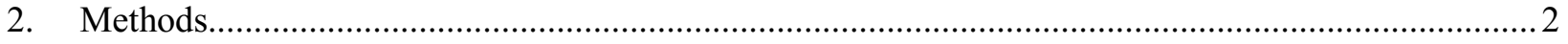

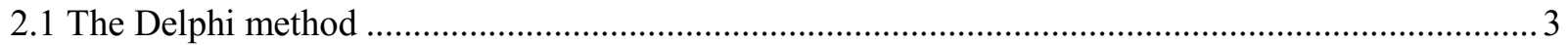

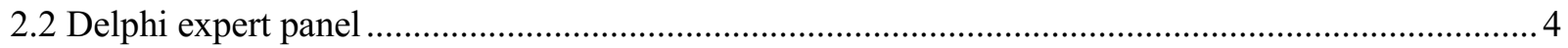

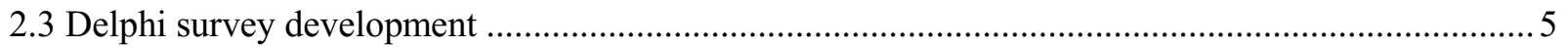

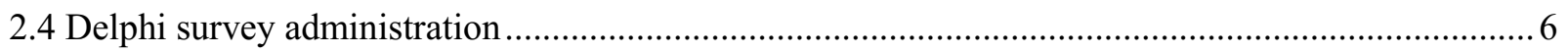

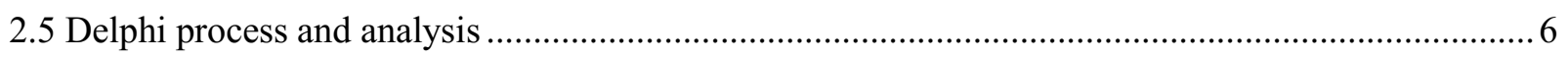

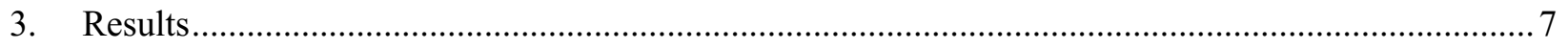

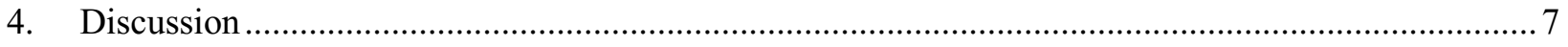

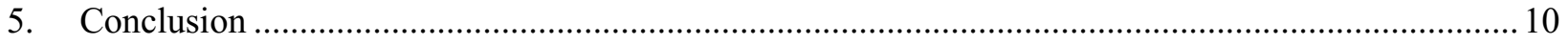

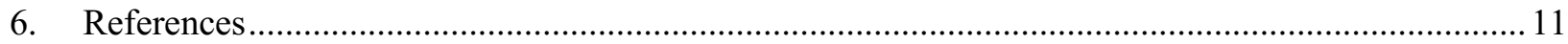

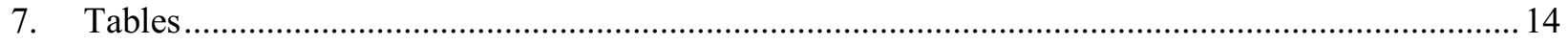

Table 1. Sociodemographic characteristics of the SaT Delphi expert panel........................................ 14

Table 2. Summary of the SaT Delphi process rounds one to three...................................................... 15

Table 3. Summary of content areas that did and did not reach consensus at after Rounds 1-3 of the SaT

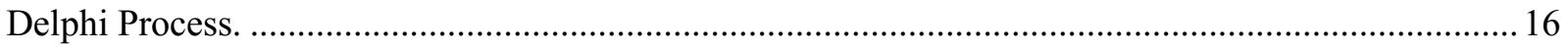

Table 4. Topics that reached consensus as essential, important, or not important for inclusion in a SaT

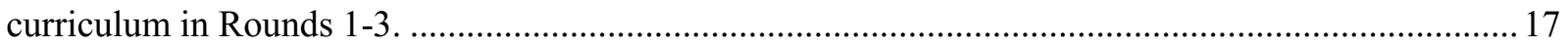

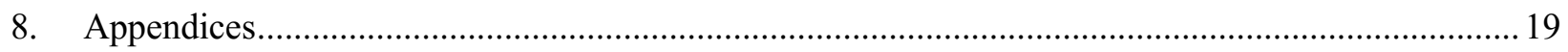

Appendix 1: Student-as-Teacher (SaT), Resident-as-Teacher (RaT), and Continuing Medical Education

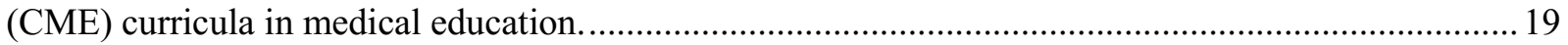

Appendix 2: SaT Delphi Round One Survey Development. ...............................................................22 


\section{List of Tables with Captions}

Table 1. Sociodemographic characteristics of the SaT Delphi expert panel.

Table 2. Summary of the SaT Delphi process rounds one to three.

Table 3. Summary of content areas that did and did not reach consensus at after Rounds 1-3 of the SaT Delphi Process. Percentages are bolded and shaded if they reached $\geq 70 \%$ consensus.

Table 4. Topics that reached consensus as essential, important, or not important for inclusion in a SaT curriculum in Rounds 1-3. 


\section{Acknowledgements}

Thank you to my co-investigators for their support, mentorship, and edits on this manuscript: Amy Sullivan EdD, Molly Brett MD, Amy R. Weinstein MD, MPH, Katharyn M. Atkins MD, and the SaT Delphi Working Group (i.e. Eva Aagaard, MD, University of Colorado School of Medicine; David Bolender, PhD, Medical College of Wisconsin; Huiju Carrie Chen, MD, MSEd, UC San Francisco; Joseph Cofrancesco Jr., MD, MPH, Johns Hopkins University School of Medicine; Ralph A. Gillies, PhD, Augusta University; Ellen Goldman, EdD, MBA, George Washington University; Steven M. Gorbatkin, MD, PhD, Emory University; Paul Gordon, MD, MPH, University of Arizona, Tucson; Wendy L. Hobson, MD, MSPH, University of Utah; Krista Hoffmann-Longtin, PhD, Indiana University; Reena Karani, MD, MHPE, Icahn School of Medicine at Mount Sinai; Michael Katzman, MD, Penn State College of Medicine; S. Lynn Knox, MD, University of Texas Medical Branch; Joseph C. Kolars, MD, University of Michigan; Alan M. Leichtner, MD, MSHPEd, Harvard Medical School; Helen Loeser, MD, MSc, UC San Francisco; Karen Marcdante, MD, Medical College of Wisconsin; Christine M. Peterson, MD, University of Virginia; Janet Riddle, MD, University of Illinois, Chicago; Richard M. Schwartzstein, MD, Harvard Medical School; Angela Sharkey, MD, Saint Louis University; Pam Shaw, MD, University of Kansas; Laura Smith-Olinde, PhD, University of Arkansas for Medical Sciences; Christine Thatcher, EdD, University of Connecticut; Paula M. Trief, PhD, SUNY Upstate Medical University; Teri Turner, MD, MPH, MEd, Baylor College of Medicine; Denham S. Ward, MD, PhD, Tufts - Maine Medical Center; Shari A. Whicker, EdD, MEd, Virginia Tech Carilion School of Medicine).

I would also like to extend my thanks to Holly Gooding, MD, MSc, Richard Schwartzstein, MD, Gordon Harper, MD, Kathleen Huth, MD, Nicholas Thibodeau-Jarry, MD, and Taylor Freret, MEd for their collaborative input and feedback on this study.

This work was conducted with support from Students in the Master of Medical Sciences in Medical Education program of Harvard Medical School. The content is solely the responsibility of the authors and does not necessarily represent the official views of Harvard University and its affiliated academic health care centers. 



\section{Background}

Residents are responsible for a significant proportion of medical student and peer teaching, but competing clinical demands make it difficult for teaching skills to be learned solely during residency, even in Resident-as-Teacher (RaT) programs (Bing-You and Sproul 1992; Dandavino et al. 2007; Snell 2011; Haber et al. 2006). Medical education accrediting bodies in the United States (US), Canada, and the United Kingdom have underscored the importance of teaching as a skill for trainees and, as such, there is growing interest in training medical students to teach nationwide (ACGME 2013; RCPSC 2015; GMC 2015).

In a survey of 99 US medical schools in 2008, nearly half (44\%) reported offering teacher-skills training to students in Student-as-Teacher (SaT) programs (Soriano et al. 2010). Typically, most SaT programs are designed to pair formal instruction in teaching with peer-teaching (also commonly referred to as "peer assisted learning") opportunities, but teaching topics and learning goals vary widely among programs (Yu et al. 2011; Ross and Cameron 2007). Given the heterogeneity of SaT curricula (Pasquinelli and Greenberg 2008; Yu et al. 2011; Burgess et al. 2014), it is important to delineate curricular priorities to ensure trainees enter their postgraduate training with teaching competencies that RaT and continuing medical education (CME) programs can build upon.

In the absence of longitudinal data describing which topics in SaT curricula best prepare trainees to serve as teachers, we sought expert opinion to establish SaT curricular priorities as a first step. Here we describe the process and results of a Delphi consensus study with a national panel of expert medical educators in the US. Panelists were tasked to reach consensus on five to ten "essential" content areas for inclusion in a SaT curriculum with the stated goal "to equip medical students with knowledge and skills to be effective clinical teachers in medical school, residency, and beyond."

\section{Methods}

Study was deemed exempt by the Beth Israel Deaconess Medical Center (Boston, MA, USA) Institutional Review Board. 


\subsection{The Delphi method}

The Delphi method is one of three main consensus methodologies used to generate expert agreement in areas with inadequate empirical evidence. Unlike other popular consensus methods (i.e., nominal group process, consensus development panel), the Delphi method does not require face-to-face contact, making it a popular choice for national and international consensus studies (Waggoner et al. 2016).

Consensus in the Delphi method is achieved by iterative rating of items in successive survey rounds (typically two to four rounds) by an expert panel (Waggoner 2016). Panelists are unaware of the identities of other panelists, which has been proposed to be one strength of the Delphi method over other consensus methods because it may help eliminate bias from dominant group member(s). Recommended size of the expert panel is at least six members and panels that exceed 12 members have not been shown to confer an increase in reliability (Nair et al. 2011). Limitations include the absence of interactive collaboration and possible increasing participant burnout with increasing survey rounds (Waggoner et al. 2016).

Importantly, because the Delphi method has undergone convergent evolution in multiple fields, there is no clearly prescribed length, format, or consensus criteria for Delphi techniques. Delphi studies generally conform to the core criteria discussed above, but they are modified in various ways according to goals of each expert panel (Waggoner et al. 2016; Diamond et al. 2014). Although heterogeneity in the Delphi process is inevitable, rigor is ensured by clearly defining consensus criteria and number of survey rounds a priori and reporting a reproducible method for recruiting panelists (Diamond et al. 2014).

Given the Delphi method's flexible format and prior use to develop healthcare curricula (Turner and Weiner 2002; Walley and Webb 1997; Fried and Leao 2007; Penciner et al. 2011; Waggoner et al. 2016), we identified the Delphi method as a suitable way to survey a nationally representative cohort of medical educators about SaT curricular priorities. To our knowledge, this is the first national Delphi study carried out for $\mathrm{SaT}$ or $\mathrm{RaT}$ programs. 


\subsection{Delphi expert panel}

The suggested criteria for selecting members of a Delphi expert panel are: knowledge and experience with issues, capacity and willingness to participate, sufficient time to participate, and effective communication skills (Skulmoski et al. 2007). To this end, through purposive sampling, the Delphi study moderators (authors JR, AS, MB, AW, KA) identified a cohort of Academy directors at US medical schools to serve on the expert panel. Academies vary in their specific goals, but their overall focus is to support the educational mission of their institution (Searle et al. 2010). As such, Academies are generally directed by experienced medical educators who the moderators felt would have a vested interest in, and the expertise to comment on, priorities for SaT curricula.

Panelists were recruited by emailing study information to US medical school Academy director members $(\mathrm{n}=63)$ of "Academies Collaborative" (www.acadmiescollaborative.com), a national forum for health professions' teaching academies and similar organizations. Twenty-eight individuals expressed interest in participating as panelists. In exchange for reviewing and contributing to the manuscript and study participation, panelists were offered co-authorship. Participation in each round was optional and no additional incentives were offered.

Of the 28 panelists, 25 were Academy directors (40\% recruitment rate) and three were identified by Academy directors as individuals at their institution with expertise in SaT-related work. Altogether, the panel ("SaT Delphi Working Group") represented 25 medical institutions in the US. By self-report, $71 \%$ (20) held MD degrees, 25\% (7) held $\mathrm{PhD} / \mathrm{EdD}$ degrees, $18 \%$ (5) held master's degrees in education, and 43\% (12) had completed a medical education fellowship. Eighty-nine percent (25) of panelists selfreported being at an academic medical institution for more than ten years. These and other characteristics of the Delphi expert panel are summarized in Table 1. 


\subsection{Delphi survey development}

To develop the round one Delphi survey, study moderators performed a literature search to identify pre-existing topics in SaT, RaT, and CME curricula. Using basic search terms (e.g., "resident as teacher" and "student as teacher") in PubMed and Google, in addition to reviewing posters/hardcopy curricula authors had previously curated, curricula from 23 institutions (9 SaT, 10 RaT, 4 CME; see Appendix 1) were identified.

Content covered in these curricula were inputted into an Excel spreadsheet (Microsoft, Redmond, WA) and grouped together by general content area to create a comprehensive list of distinct curricular topics. We identified 28 unique topics and organized these into eight thematic domains. A short noncomprehensive list of sub-topics was listed next to each topic to ground it in tangible learning activities (Appendix 2). For example, written next to the topic, "Procedural and skills-based teaching" was the subtopic description, “(e.g., how to teach a clinical skill or procedure such as suturing, lumbar puncture, auscultating, etc.)."

Topics and associated sub-topic descriptions were organized by domain and put in the round one Delphi survey for panelists to rate on a 3-point scale (1-“essential," 2-“important but not essential," 3"not important"). Instructions were given to guide panelists in rating of topics:

"Our goal is to identify 5-10 core 'essential' topics to prepare ALL medical students for their roles as teachers. Topics that are 'important, but not essential' may be considered for further study by students with a particular interest in medical education. Topics that are 'not important' do not belong in a SaT curriculum for medical students."

To ensure clear phrasing of topics and sub-topic examples, the round one survey was piloted with two physicians who were Harvard Medical School masters in medical education students and one fourthyear Harvard medical student pursuing a master's in education. These individuals gave feedback about the phrasing and clarity of medical education topics. 


\subsection{Delphi survey administration}

SaT Delphi surveys were administered anonymously using the online survey software Qualtrics (Qualtrics, Provo, UT). In the round one survey, 28 finalized topics were presented in eight blocks (i.e., pages). Each block corresponded to a thematic domain. Blocks and the topics within them were presented to panelists in random order to minimize bias due to ordering effects. Each block had an optional freeresponse textbox for panelists to comment on their rationale for their ratings.

At the top of each page in the survey, the cumulative number of topics each panelist had selected as "essential" was displayed. Panelists were encouraged not to select more than five to ten topics as "essential" (a range chosen by moderators based on the number of content areas that could be feasibly covered in a two to four-week elective or longitudinally over an academic year, which are commonly cited formats of SaT programs (Soriano et al. 2010)). As described below, new and modified topics were included in subsequent survey rounds. Presentation of the topics described above (i.e., organized by domain and in random order) was the same for each round.

\subsection{Delphi process and analysis}

The moderators decided a priori there would be a minimum of two and maximum of three survey rounds, typical of most Delphi studies (Waggoner 2016). Because consensus on all topics had not been reached at the end of round two, three survey rounds were administered monthly, from April 2016 to June 2016. As many Delphi studies use percentage agreement to define consensus (Diamond et al. 2014), a threshold of $\geq 70 \%$ percent agreement on the 3-point scale was used to define "consensus" in this study.

After each round, free-text comments were reviewed by authors JR and KA. Specific wording modifications and suggestions were highlighted in each round. Topics were created, modified, and/or combined if they aligned with study goals and did not conflict with the other participants' free-text comments. Decisions about wording modifications and creation of new topics were made after a discussion between JR and KA to resolve any areas of disagreement. 
Newly suggested topics, modified topics, and those that did not reach quantitative consensus were included in subsequent rounds for panelists' re-consideration. Topics that reached $\geq 70 \%$ consensus as “essential," "important," or "not important" were accepted and removed from remaining rounds unless qualitative comments offered specific suggestions for modification. In the latter case, these topics were modified and re-included in the next survey round.

At the start of rounds two and three, panelists received anonymized summary statistics (i.e., aggregate percentages for each topic and panelists' free-text comments) from the previous round. Panelists were encouraged to use the statistics to inform their rating of topics in the next round to move toward group consensus.

\section{Results}

Twenty-eight panelists $(100 \%)$ responded to each survey round. Most of the consensus was achieved in rounds two and three (Table 2). At the end of the three survey rounds, 19 topics reached consensus as "essential," "important," or "not important," and 16 topics did not reach consensus (Table 3).

Five content areas reached consensus as "essential" for inclusion SaT curricula (Table 4). In decreasing order of consensus, essential topics were: feedback (100\% consensus), bedside teaching and clinical precepting (86\% consensus), small-group teaching (75\% consensus), case-based teaching (71\% consensus), and professionalism as a medical educator (71\% consensus). Thirteen topics achieved consensus as "important" and only one topic (i.e., history of medical education) reached consensus as "not important" for inclusion in a SaT curriculum (Table 4).

\section{Discussion}

The national Delphi survey of US medical educators we conducted is a first step toward defining SaT curricular priorities. It is notable that topics that achieved consensus as "essential" (i.e., feedback, bedside teaching and clinical precepting, small-group teaching, case-based teaching, professionalism as a 
medical educator) are arguably more "hands-on" and skill-based than theory-based topics (e.g., cognitive science, experiential learning theory) that did not reach consensus as either essential or important (Table 3). In general, panelists' tendency to prioritize skills over theory may have been driven, in part, by the stated study goal to practically prepare medical students for their teaching roles in residency and beyond. Notably, however, in free-text boxes of the survey, panelists expressed varied opinions about the relative weight that should be given to theory versus skill in a SaT curriculum. In support of skills over theory, for example, one panelist commented, "given the task of helping med students "hit the ground running" as teachers, I think conveying much/many theory information should take a distant second to practical and applied information...the "how-to" (Round 3)

On the other hand, some panelists argued that the view that skills are more important than theory may undermine the view of learning as a "science," and should be re-considered:

"I worry about excluding any learning science at all. Medical students who become teachers must understand that there is a SCIENCE of how people learn, and often we ignore this science in medical education (for example, our heavy reliance on didactic lecture)" (Round 3)

Despite some areas of disagreement, the panelists' overall consensus (defined a priori as $\geq 70 \%$ agreement on the 3-point scale) on "essential" topics largely reflects trends in existing SaT programs. Topics that reached high degrees of consensus as "essential" in this study (e.g., small-group teaching and feedback) are already predominant content areas of current medical student teacher-skills training programs in the US, for example (Soriano et al. 2010). The only popular content area in current US-based SaT and RaT curricula that was not rated as "essential" by the SaT Delphi panelists was "adult learning theory" (Soriano et al. 2010). To avoid redundancy in RaT programs, prioritization of skills-based topics (e.g., case-based teaching) may be considered in lieu of more theoretical topics like "adult learning theory" in SaT programs given quantitative consensus results from this study. In either case, we recommend that curricular contexts, medical student interests, and institutional resources should be 
considered alongside the consensus rating of topics by experts in this study when designing or enhancing pre-existing SaT programs.

It is important to note that some topics that did not reach consensus as essential (e.g., oral presentation skills, procedural and skills-based teaching) have a strong consensus as "essential" and "important" if the percentage agreements in these categories are summed together (Table 3). Therefore, in our effort to identify 5-10 "essential topics," the relative importance of other topics is less clear. We envision "important" topics, and those topics which did not or nearly reached consensus, as ones which could be pursued independently by students with interests in medical education if they cannot be included in the formal SaT curriculum.

Next steps include creation of learning objectives and competencies for essential and important content areas. Although specific learning objectives have been suggested for SaT programs (Blanco et al. 2014), to our knowledge, competencies that describe applied actions of skills, attitude, and knowledge have yet to be proposed. In a follow-up online survey to Delphi participants after the conclusion of the three survey rounds, the moderators collected preliminary thoughts about learning objectives for essential topics from the expert panel (data not reported), but concluded that, due to heterogeneity of responses and decreased response rate, an in-person consensus process would be required to create them. Involving other stakeholder perspectives (e.g., medical students and residents) will also be valuable to verify and refine topics identified from this study's faculty-only panel.

An in-person consensus process will also be an opportunity to consider "milestones" for learners along the continuum of RaT-SaT-CME teaching skills programs in accordance with the movement toward competency-based frameworks in medical education (Englander et al. 2015; Carraccio et al. 2002; Frank et al. 2010). In particular, some of the SaT Delphi panelists' free text comments underscore the point that medical students are themselves trainees. One panelist reflected that, "self-directed learning skills provide the link between the experiences of learning and of being an effective teacher" (Round 2) 
This sentiment was echoed by other panelists and it is notable that the topic of "self-directed learning skills" did reach consensus as "important" (71\% agreement). To this point, it may be beneficial to develop competencies and milestones for SaT programs that are not only limited to "teaching" skills, but that also incorporate strategies for effective lifelong learning.

Results of this study must be interpreted in the context of our study design. The multiple-choice survey design and quantitative cut-off for consensus limited a more nuanced discussion of topics and wording modifications. Moreover, although the a priori definition of consensus was defined in accordance with prior Delphi studies as $\geq 70 \%$ agreement, this is an arbitrary cut-off, which is why we present raw percentage-agreement scores of all topics in Table 3. Although this was a small crosssectional survey design $(\mathrm{n}=28)$, this study reflects a near comprehensive cross-section of academic medical institutions in the US. Generalizability of the study may be limited by unique characteristics of medical educators in the expert panel.

\section{Conclusion}

Results of this Delphi study with national experts offer guidance to educators who wish to prioritize topics in existing or planned SaT programs. By identifying five "essential" content areas, we hope it is more feasible to include SaT training in crowded medical school curricula and facilitate better integration with RaT programs. Our findings are an important first step toward creating general competencies for SaT programs with the intention to prepare medical students to excel as teachers during their medical training and beyond. 


\section{References}

Accreditation Council for Graduate Medical Education (ACGME) [Internet]. 2013. Common Program Requirements. [cited 2017 Mar 6]. Available from: http://www.acgme.org/What-WeDo/Accreditation/Common-Program-Requirements.

Bing-You RG, Sproul MS. 1992. Medical Students' Perceptions of Themselves and Residents as Teachers. Med Teach 14:133.

Blanco MA, Maderer A, Oriel A, Epstein SK. 2014. How We Launched a Developmental Student-asTeacher (SAT) Program for All Medical Students. Med Teach 36:385-89.

Burgess A, McGregor D, Mellis C. 2014. Medical Students as Peer Tutors: A Systematic Review. BMC Med Educ 14:115.

Carraccio D, Wolfsthal D, Englander D, Ferentz D, Martin D. 2002. Shifting Paradigms: From Flexner to Competencies. Acad Med 77: 361-367.

Dandavino M, Snell L, Wiseman J. 2007. Why Medical Students Should Learn How to Teach. Med Teach 29:558-565.

Diamond IR, Grant RC, Feldman BM, Pencharz PB, Ling SC, Moore AM, Wales PW. 2014. Defining Consensus: A Systematic Review Recommends Methodologic Criteria for Reporting of Delphi Studies. J Clin Epidemiol 67:401-9.

Englander R, Cameron T, Addams A, Bull J, Jacobs J. 2015 [Internet]. Understanding Competency-Based Medical Education. AM Rounds; [cited 2017 Mar 6]. Available from: http://academicmedicineblog.org/understanding-competency-based-medical-education/.

Frank JR, Snell LS, Cate OT, Holmboe ES, Carraccio C, Swing SR, Harris P, Glasgow N, Campbell C, Dath D, et al. 2010. Competency-Based Medical Education: Theory to Practice. Med Teach $32: 638-645$.

Fried H, Leao AT. 2007. Using Delphi Technique in a Consensual Curriculum for Periodontics. J Dent Educ 71:1441-46.

General Medical Council (GMC) [Internet]. 2015. Outcomes for Graduates. [cited 2017 Mar 6]. Available 
from: http://www.gmcuk.org/education/undergraduate/undergrad_outcomes.asp.

Haber RJ, Bardach NS, Vedanthan R, Gillum LA, Haber LA, Dhaliwal GS. 2006. Preparing Fourth-Year Medical Students to Teach During Internship. J Gen Intern Med 21:518-20.

Nair R, Aggarwal R, Khanna D. 2011. Methods of Formal Consensus in Classification/Diagnostic Criteria and Guideline Development. Semin Arthritis Rheum 41:95-105.

Pasquinelli LM, Greenberg LW. 2008. A Review of Medical School Programs That Train Medical Students as Teachers (MED-SATS). Teach Learn Med 20:73-81.

Penciner R, Langhan T, Lee R, McEwen J, Woods RA, Bandiera G. 2011. Using a Delphi Process to Establish Consensus on Emergency Medicine Clerkship Competencies. Med Teach 33:e333-339.

Ross MT, Cameron HS. 2007. Peer Assisted Learning: A Planning and Implementation Framework: AMEE Guide No. 30. Med Teach 29:527-45.

Royal College of Physicians and Surgeons of Canada (RCPSC) [Internet]. 2015. CanMEDS 2015 Physician Competency Framework. [cited 2017 Mar 6]. Available from: http://canmeds.royalcollege.ca/en/framework.

Searle S, Thompson M, Friedland A, Lomax W, Drutz E, Coburn A, Nelson A. 2010. The Prevalence and Practice of Academies of Medical Educators: A Survey of U.S. Medical Schools. Acad Med $85: 48-56$.

Skulmoski GJ, Hartman FT, Krahn J. 2007. The Delphi Method for Graduate Research. Journal of Information Technology Education 6:1-21.

Snell L. 2011. The Resident-as-Teacher: It's More Than Just About Student Learning. J Grad Med Educ $3: 440-41$.

Soriano RP, Blatt B, Coplit L, Cichoskikelly E, Kosowicz L, Newman L, Pasquale SJ, Pretorius R, Rossen JM, Saks NS, Greenberg L. 2010. Teaching Medical Students How to Teach: A National Survey of Students-as-Teachers Programs in U.S. Medical Schools. Acad Med 85:1725-1731.

Turner GH, Weiner DK. 2002. Essential Components of a Medical Student Curriculum on Chronic Pain Management in Older Adults: Results of a Modified Delphi Process. Pain Med 3:240-52. 
Waggoner J, Carline JD, Durning SJ. 2016. Is There a Consensus on Consensus Methodology?

Descriptions and Recommendations for Future Consensus Research. Acad Med 91:663-68.

Walley T, Webb DJ. 1997. Developing a Core Curriculum in Clinical Pharmacology and Therapeutics: A Delphi Study. Br J Clin Pharmacol 44:167-70.

Yu TC, Wilson NC, Singh PP, Lemanu DP, Hawken SJ, Hill AG. 2011. Medical Students-as-Teachers: A Systematic Review of Peer-Assisted Teaching during Medical School. Adv Med Educ Pract 2:157-72. 


\section{Tables}

Table 1. Sociodemographic characteristics of the SaT Delphi expert panel.

\begin{tabular}{|c|c|}
\hline Variable & $\begin{array}{l}\mathbf{n}=\mathbf{2 8} \\
\mathbf{n}(\%)\end{array}$ \\
\hline \multicolumn{2}{|l|}{ Academic rank } \\
\hline Assistant professor & $4(14)$ \\
\hline Associate professor & $8(29)$ \\
\hline Professor & $16(57)$ \\
\hline \multicolumn{2}{|l|}{ Professional training } \\
\hline MD & $20(71)$ \\
\hline $\mathrm{PhD} / \mathrm{EdD}$ & $7(25)$ \\
\hline Master's degree in education & $5(18)$ \\
\hline Fellowship in medical education & $12(43)$ \\
\hline Continuing medical education in medical education & $14(50)$ \\
\hline \multicolumn{2}{|c|}{$\begin{array}{l}\text { Years practicing as an academic physician (for MD educators) or years at an academic medical } \\
\text { institution (for non-MD educators) }\end{array}$} \\
\hline $0-5$ years & $1(4)$ \\
\hline$>5$ and up to 10 years & $2(7)$ \\
\hline$>10$ and up to 20 years & $8(29)$ \\
\hline$>20$ years & $17(61)$ \\
\hline \multicolumn{2}{|c|}{ Proportion of time presently involved in teaching medical students } \\
\hline $0-24 \%$ & $16(57)$ \\
\hline $25-49 \%$ & $7(25)$ \\
\hline $50-74 \%$ & $4(14)$ \\
\hline $75-100 \%$ & $1(4)$ \\
\hline \multicolumn{2}{|c|}{$\begin{array}{l}\text { Proportion of time presently involved in medical education administrative work, faculty } \\
\text { development, and/or curriculum development }\end{array}$} \\
\hline $0-24 \%$ & $2(7)$ \\
\hline $25-49 \%$ & $6(21)$ \\
\hline $50-74 \%$ & $10(36)$ \\
\hline $75-100 \%$ & $10(36)$ \\
\hline
\end{tabular}


Table 2. Summary of the SaT Delphi process rounds one to three.

\begin{tabular}{|l|l|l|l|l|l|}
\hline & $\begin{array}{l}\text { Total number } \\
\text { of topics }\end{array}$ & $\begin{array}{l}\text { Goal of the } \\
\text { round }\end{array}$ & $\begin{array}{l}\text { Topics that } \\
\text { reached } \\
\text { qualitative and } \\
\text { quantitative } \\
\mathbf{2 7 0 \% )} \\
\text { consensus and } \\
\text { were accepted }\end{array}$ & $\begin{array}{l}\text { Topics that } \\
\text { reached } \\
\text { quantitative } \\
\text { consensus, but } \\
\text { were revised } \\
\text { based on } \\
\text { qualitative } \\
\text { comments and } \\
\text { included in the } \\
\text { next round }\end{array}$ & $\begin{array}{l}\text { Topics that did } \\
\text { not reach } \\
\text { qualitative or } \\
\text { quantitative } \\
\text { consensus* }\end{array}$ \\
\hline Round 1 & & $\begin{array}{l}\text { New topics } \\
\text { generated } \\
\text { from } \\
\text { qualitative } \\
\text { comments }\end{array}$ \\
\hline Round 2 & 28 & 30 & Exploratory & 4 & 1 \\
\hline Round 3 & 21 & Clarifying & 10 & 2 & 23 \\
\hline
\end{tabular}

*for rounds one and two, these topics were included (with or without modifications) in the next round 
Table 3. Summary of content areas that did and did not reach consensus at after Rounds 1-3 of the SaT Delphi Process. Percentages are bolded and shaded if they reached $\geq 70 \%$ consensus.

\begin{tabular}{|c|c|c|c|}
\hline \multirow[t]{2}{*}{ Topic (Round in which consensus was achieved or not achieved) } & \multicolumn{3}{|c|}{ \% Agreement } \\
\hline & Essential & $\begin{array}{l}\text { Important, but } \\
\text { not essential }\end{array}$ & Not important \\
\hline \multicolumn{4}{|l|}{5 topics reached consensus as "essential" } \\
\hline Feedback (2) & 100 & 0 & 0 \\
\hline Bedside teaching and precepting in clinical contexts (2) & 86 & 14 & 0 \\
\hline Small-group teaching (1) & 75 & 25 & 0 \\
\hline Case-based teaching (2) & 71 & 25 & 4 \\
\hline Professionalism as a medical educator (2) & 71 & 29 & 0 \\
\hline \multicolumn{4}{|l|}{13 topics reached consensus as "important" } \\
\hline Digital innovations in teaching and learning (2) & 4 & 89 & 7 \\
\hline Scholarship in medical education (3) & 4 & 82 & 14 \\
\hline Curriculum planning (3) & 4 & 79 & 18 \\
\hline High-fidelity patient simulation teaching (1) & 0 & 75 & 25 \\
\hline Interprofessional teaching (1) & 21 & 75 & 4 \\
\hline Large-group teaching (1) & 18 & 75 & 7 \\
\hline Competency-based assessment (2) & 14 & 75 & 11 \\
\hline Instructional trends in medical education (2) & 7 & 75 & 18 \\
\hline Problematic teaching and learning encounters (2) & 11 & 75 & 14 \\
\hline How to write SMART objectives (3) & 21 & 75 & 4 \\
\hline Peer observation and metacognition (2) & 21 & 71 & 7 \\
\hline Self-directed learning principles (2) & 29 & 71 & 0 \\
\hline How to activate prior knowledge (3) & 25 & 71 & 4 \\
\hline \multicolumn{4}{|l|}{1 topic reached consensus as "not important" } \\
\hline History of medical education (3) & 0 & 25 & 75 \\
\hline \multicolumn{4}{|l|}{16 topics did NOT reach consensus } \\
\hline Oral presentation skills (3) & 68 & 32 & 0 \\
\hline How to actively engage learners (3) & 57 & 39 & 4 \\
\hline Learning environment (3) & 46 & 54 & 0 \\
\hline Teaching patients (3) & 36 & 43 & 21 \\
\hline The hidden/informal curriculum (3) & 32 & 61 & 7 \\
\hline Procedural and skills-based teaching (3) & 29 & 50 & 21 \\
\hline $\begin{array}{l}\text { How to align learning objectives, instructional activities, } \\
\text { and learner assessment strategies (3) }\end{array}$ & 29 & 68 & 4 \\
\hline Providing clear instructional tools (3) & 25 & 64 & 11 \\
\hline Cognitive science principles for teaching and learning (3) & 21 & 46 & 32 \\
\hline Mindfulness (3) & 18 & 54 & 29 \\
\hline Learning how to lead clinical teams (3) & 18 & 64 & 18 \\
\hline Learning styles (3) & 7 & 64 & 29 \\
\hline Career development as a medical educator ( 3 ) & 7 & 57 & 36 \\
\hline Program evaluation (3) & 4 & 54 & 43 \\
\hline Experiential learning theory (3) & 0 & 54 & 46 \\
\hline Teaching through arts \& the humanities (3) & 0 & 36 & 64 \\
\hline
\end{tabular}


Table 4. Topics that reached consensus as essential, important, or not important for inclusion in a SaT curriculum in Rounds 1-3.

\begin{tabular}{|c|c|c|c|c|}
\hline & Topic & $\begin{array}{l}\% \\
\text { agreement }\end{array}$ & $\begin{array}{l}\text { When was } \\
\text { consensus } \\
\text { reached }\end{array}$ & $\begin{array}{l}\text { Selected optional comments in support of } \\
\text { the topic's final rating by members of the } \\
\text { Delphi expert panel }\end{array}$ \\
\hline \multirow[t]{5}{*}{ Essential (5) } & Feedback & 100 & Round 2 & $\begin{array}{l}\text { "Feedback giving and taking is essential to } \\
\text { teaching and learning." Round } 2\end{array}$ \\
\hline & $\begin{array}{l}\text { Bedside teaching and } \\
\text { precepting in clinical contexts }\end{array}$ & 86 & Round 2 & $\begin{array}{l}\text { "Precepting skills such as OMP and SNAPPS } \\
\text { require the core teaching skills of questioning } \\
\text { and giving feedback. Clinical precepting can } \\
\text { then become the "case study" for learning to use } \\
\text { these skills in other contexts." Round } 1\end{array}$ \\
\hline & Small-group teaching & 75 & Round 1 & $\begin{array}{l}\text { "Extra instruction in problem based learning } \\
\text { and small group discussion is essential during } \\
\text { medical school because in many programs, the } \\
\text { medical students are not only learners, but are } \\
\text { also key teachers of their fellow medical } \\
\text { students in these settings." Round } 1\end{array}$ \\
\hline & Case-based teaching & 71 & Round 2 & $\begin{array}{l}\text { "Case based teaching is the way most medical } \\
\text { students learn illness scripts and critical } \\
\text { thinking skills, so I believe it is essential." Round } \\
2\end{array}$ \\
\hline & $\begin{array}{l}\text { Professionalism as a medical } \\
\text { educator }\end{array}$ & 71 & Round 2 & $\mathrm{~N} / \mathrm{A}$ \\
\hline \multirow[t]{10}{*}{ Important (13) } & $\begin{array}{l}\text { Digital innovations in teaching } \\
\text { and learning }\end{array}$ & 89 & Round 2 & $\begin{array}{l}\text { "I believe that digital innovations are going to } \\
\text { increase, but don't believe we need to create } \\
\text { residents who develop these - exposure to the } \\
\text { various strategies would be important but not } \\
\text { essential." Round } 1\end{array}$ \\
\hline & $\begin{array}{l}\text { Scholarship in medical } \\
\text { education }\end{array}$ & 82 & Round 3 & $\begin{array}{l}\text { "Scholarship is important because it can set } \\
\text { medical students up for the future of their } \\
\text { career" } \\
\text { Round } 3 \\
\text { "We must teach students how to track what they } \\
\text { do (or they won't be allowed to do it for very } \\
\text { long)." Round } 3\end{array}$ \\
\hline & Curriculum planning & 79 & Round 3 & $\begin{array}{l}\text { "They are not likely to be creating curricula and } \\
\text { assessments; they need actual teaching skills to } \\
\text { be applied to an individual or groups of } \\
\text { learners." Round } 3\end{array}$ \\
\hline & $\begin{array}{l}\text { High-fidelity patient simulation } \\
\text { teaching }\end{array}$ & 75 & Round 1 & $\begin{array}{l}\text { "Given our time constraints, I think sim is a } \\
\text { topic that could be explored after medical } \\
\text { school. I make this decision based on the } \\
\text { assumption that all students would have at least } \\
\text { experienced some simulated activity as a } \\
\text { learner." Round } 1\end{array}$ \\
\hline & Interprofessional teaching & 75 & Round 1 & $\mathrm{~N} / \mathrm{A}$ \\
\hline & Large-group teaching & 75 & Round 1 & $\begin{array}{l}\text { "Large group teaching is a bit of a conundrum. } \\
\text { We actually expect residents to provide didactic } \\
\text { lectures to large groups - and learning basics of } \\
\text { creating slides as well as a focus on presentation } \\
\text { skills is often desired. I still think that it i[s] only } \\
\text { "important" and not essential based on the } \\
\text { majority of their teaching which occurs in the } \\
\text { clinical setting." Round } 1\end{array}$ \\
\hline & Competency-based assessment & 75 & Round 2 & $\begin{array}{l}\text { "Learning about CBME [competency based } \\
\text { medical education] can help student[s] become } \\
\text { better learners - and so is important." Round } 2\end{array}$ \\
\hline & $\begin{array}{l}\text { Instructional trends in medical } \\
\text { education }\end{array}$ & 75 & Round 2 & $\mathrm{~N} / \mathrm{A}$ \\
\hline & $\begin{array}{l}\text { Problematic teaching and } \\
\text { learning encounters }\end{array}$ & 75 & Round 2 & $\begin{array}{l}\text { "Working to resolve problematic encounters is } \\
\text { important, but developing a remediation plan is } \\
\text { not important for medical students." Round } 1\end{array}$ \\
\hline & How to write SMART objectives & 75 & Round 3 & $\begin{array}{l}\text { "I think SMART objectives are core to } \\
\text { developing any learning opportunity that is } \\
\text { planned. Everyone who is teaching should } \\
\text { understand how to do so." Round } 3\end{array}$ \\
\hline
\end{tabular}




\begin{tabular}{|l|l|l|l|l|}
\hline & $\begin{array}{l}\text { Peer observation and } \\
\text { metacognition }\end{array}$ & 71 & Round 2 & $\begin{array}{l}\text { "[...] observing teaching is very important. } \\
\text { Teachers (in health professions education) are } \\
\text { rarely observed - and yet much can be learned } \\
\text { from observation and reflection. Metacognitive } \\
\text { strategies are an important part of learning how } \\
\text { to become a better teacher. And metacognition } \\
\text { can result from careful feedback and debriefing } \\
\text { after peer observation." Round 1 }\end{array}$ \\
\hline & $\begin{array}{l}\text { Self-directed learning } \\
\text { principles }\end{array}$ & 71 & $\begin{array}{l}\text { "Self-directed learning skills provide the link } \\
\text { between the experiences of learning and of } \\
\text { being an effective teacher. As we need to be } \\
\text { selective in this Delphi process, I am more } \\
\text { ambivalent about the "essential" value of self- } \\
\text { directed learning skills in a students as teachers } \\
\text { curriculum." Round 2 }\end{array}$ \\
\hline Not important & $\begin{array}{l}\text { How to activate prior } \\
\text { knowledge }\end{array}$ & History of medical education & 75 & Round 3 \\
(1) & 71 & Round 3 \\
be important for learning [...]" Round 2
\end{tabular}




\section{Appendices}

\section{Appendix 1: Student-as-Teacher (SaT), Resident-as-Teacher (RaT), and Continuing Medical Education}

(CME) curricula in medical education.

Table 1. SaT curricula

\begin{tabular}{|c|c|}
\hline Medical School & Citation of documents reviewed \\
\hline $\begin{array}{l}\text { George Washington University } \\
\text { (DC, United States) }\end{array}$ & $\begin{array}{l}\text { Blatt B, Greenberg L. A multi-level assessment of a program to teach medical } \\
\text { students to teach. Adv Health Sci Educ Theory Pract. } 2007 \text { Feb;12(1):7-18. }\end{array}$ \\
\hline $\begin{array}{l}\text { Iowa University } \\
\text { (IA, United States) }\end{array}$ & $\begin{array}{l}\text { Office of Consultation and Research in Medical Education, Iowa University } \\
\text { School of Medicine. 050:300 Weekly Schedule, January, } 2013 \text { [course } \\
\text { schedule]. } 2013 \text {. } \\
\text { Petit J, Ferguson K. 050:300 Teaching Skills for Medical Students M4 } \\
\text { Elective Course Fall 2013-Spring 2014 [course syllabus]. 2013. }\end{array}$ \\
\hline $\begin{array}{l}\text { Tufts University } \\
\text { (MA, United States) }\end{array}$ & $\begin{array}{l}\text { Blanco MA, Maderer A, Oriel A, Epstein SK. How we launched a } \\
\text { developmental student-as-teacher (SAT) program for all medical students. } \\
\text { Med Teach. } 2014 \text { May;36(5):385-9. } \\
\text { Tufts School of Medicine. Medical Education Elective } 2014 \text { [course } \\
\text { calendar]. } 2013 \text {. }\end{array}$ \\
\hline $\begin{array}{l}\text { University of British Columbia } \\
(B C, \text { Canada) }\end{array}$ & $\begin{array}{l}\text { Craig JL, Page G. Teaching in medicine: an elective course for third-year } \\
\text { students. Med Educ. } 1987 \text { Sep;21(5):386-90. }\end{array}$ \\
\hline $\begin{array}{l}\text { University of California San } \\
\text { Francisco } \\
\text { (CA, United States) }\end{array}$ & $\begin{array}{l}\text { Bardach NS, Vedanthan R, Haber RJ. 'Teaching to teach': enhancing fourth } \\
\text { year medical students' teaching skills. Med Educ. } 2003 \text { Nov;37(11):1031-2. } \\
\text { Haber RJ, Bardach NS, Vedanthan R, Gillum LA, Haber LA, Dhaliwal GS. } \\
\text { Preparing fourth-year medical students to teach during internship. J Gen } \\
\text { Intern Med. } 2006 \text { May;21(5):518-20. }\end{array}$ \\
\hline $\begin{array}{l}\text { University of Massachusetts } \\
\text { (MA, United States) }\end{array}$ & $\begin{array}{l}\text { Pasquale SJ, Pugnaire MP. Preparing medical students to teach. Acad Med. } \\
2002 \text { Nov;77(11):1175-6. }\end{array}$ \\
\hline $\begin{array}{l}\text { University Medical Center } \\
\text { Utrecht (The Netherlands) }\end{array}$ & $\begin{array}{l}\text { Zijdenbos I, Fick T, ten Cate O. How we offer all medical students training in } \\
\text { basic teaching skills. Med Teach. 2011;33(1):24-6. }\end{array}$ \\
\hline $\begin{array}{l}\text { University of Michigan } \\
\text { (MI, United States) }\end{array}$ & $\begin{array}{l}\text { University of Michigan School of Medicine. Resident as Teacher } 4^{\text {th }} \text { Year } \\
\text { Elective February } 10^{\text {th }} \text { to March } 7^{\text {th }} 2014 \text { schedule [course calendar]. } 2014 .\end{array}$ \\
\hline $\begin{array}{l}\text { University of Tuebingen } \\
\text { (Germany) }\end{array}$ & $\begin{array}{l}\text { Shiozawa T, Hirt B, Celebi N, Baur F, Weyrich P, Lammerding-Köppel M. } \\
\text { Development and implementation of a technical and didactical training } \\
\text { program for student tutors in the dissection course. Ann Anat. } 2010 \mathrm{Dec} \\
\text { 20;192(6):355-60. } \\
\text { Weyrich P, Celebi N, Schrauth M, Moltner A, Lammerding-Koppel M, } \\
\text { Nikendei C. Peer-assisted versus faculty staff-led skills laboratory training: a } \\
\text { randomised controlled trial. Med Educ. 2009;43(2): 113-120 }\end{array}$ \\
\hline
\end{tabular}


Table 2. RaT curricula

\begin{tabular}{|c|c|}
\hline Institution/Organization & Citation of documents reviewed \\
\hline $\begin{array}{l}\text { Beth Israel Deaconess Medical } \\
\text { Center, Internal Medicine } \\
\text { (MA, United States) }\end{array}$ & $\begin{array}{l}\text { Smith CC, McCormick I, Huang GC. The clinician-educator track: training } \\
\text { internal medicine residents as clinician-educators. Acad Med. } 2014 \\
\text { Jun;89(6):888-91. } \\
\text { Newman L, Tibbles C, Atkins KM, Burgin S, Fisher L, Kent T, Smith C, } \\
\text { Aluko A, Ricciotti H. BIDMC Resident-as-Teacher Multidisciplinary DVD } \\
\text { Series Curriculum. Poster presented at: The Harvard Medical School Academy } \\
\text { Resident/Fellow As Teacher Curriculum Showcase; September 2014; Boston, } \\
\text { MA. }\end{array}$ \\
\hline $\begin{array}{l}\text { Beth Israel Deaconess Medical } \\
\text { Center, Dermatology } \\
\text { (MA, United States) }\end{array}$ & $\begin{array}{l}\text { Burgin S, Newman L. The Harvard Dermatology Resident-as-Teacher } \\
\text { Program. Poster presented at: The Harvard Medical School Academy } \\
\text { Resident/Fellow As Teacher Curriculum Showcase; September 2014; Boston, } \\
\text { MA. }\end{array}$ \\
\hline $\begin{array}{l}\text { Brigham and Women's } \\
\text { Hospital, Internal Medicine } \\
\text { (MA, United States) }\end{array}$ & $\begin{array}{l}\text { Julian KA, Monaghan C, Wamsley MA, Wipf JE, Zabar S. Residents-as- } \\
\text { teachers curricula: how to initiate, evaluate, and sustain. } 27^{\text {th }} \text { annual SGIM } \\
\text { Meeting. Society of General Internal Medicine. } \\
\text { http://impak.sgim.org/userfiles/file/AMHandouts/AM04/Workshops/WB08.pd } \\
\text { f Published May 2004. Accessed October } 2014 \text {. }\end{array}$ \\
\hline $\begin{array}{l}\text { National survey of US pediatric } \\
\text { program directors }\end{array}$ & $\begin{array}{l}\text { Fromme HB, Whicker SA, Paik S, Konopasek L, Koestler JL, Wood B, } \\
\text { Greenberg L. Pediatric Resident-as-Teacher Curricula: A National Survey of } \\
\text { Existing Programs and Future Needs. J Grad Med Educ. } 2011 \text { Jun;3(2):168- } \\
75 .\end{array}$ \\
\hline $\begin{array}{l}\text { New York University } \\
\text { (NY, United States) }\end{array}$ & $\begin{array}{l}\text { Julian KA, Monaghan C, Wamsley MA, Wipf JE, Zabar S. Residents-as- } \\
\text { teachers curricula: how to initiate, evaluate, and sustain. } 27^{\text {th }} \text { annual SGIM } \\
\text { Meeting. Society of General Internal Medicine. } \\
\text { http://impak.sgim.org/userfiles/file/AMHandouts/AM04/Workshops/WB08.pd } \\
\text { f Published May 2004. Accessed October } 2014 .\end{array}$ \\
\hline $\begin{array}{l}\text { University of Auckland } \\
\text { (New Zealand) }\end{array}$ & $\begin{array}{l}\text { Hill AG, Srinivasa S, Hawken SJ, Barrow M, Farrell SE, Hattie J, Yu TC. } \\
\text { Impact of a Resident-as-Teacher Workshop on Teaching Behavior of Interns } \\
\text { and Learning Outcomes of Medical Students. J Grad Med Educ. } 2012 \\
\text { Mar;4(1):34-41. }\end{array}$ \\
\hline $\begin{array}{l}\text { University of California Irvine } \\
\text { (CA, United States) }\end{array}$ & $\begin{array}{l}\text { Morrison EH, Rucker L, Boker JR, Hollingshead J, Hitchcock MA, Prislin } \\
\text { MD, Hubbell FA. A pilot randomized, controlled trial of a longitudinal } \\
\text { residents-as-teachers curriculum. Acad Med. } 2003 \text { Jul;78(7):722-9. }\end{array}$ \\
\hline $\begin{array}{l}\text { University of California San } \\
\text { Francisco } \\
\text { (CA, United States) }\end{array}$ & $\begin{array}{l}\text { Julian KA, Monaghan C, Wamsley MA, Wipf JE, Zabar S. Residents-as- } \\
\text { teachers curricula: how to initiate, evaluate, and sustain. } 27^{\text {th }} \text { annual SGIM } \\
\text { Meeting. Society of General Internal Medicine. } \\
\text { http://impak.sgim.org/userfiles/file/AMHandouts/AM04/Workshops/WB08.pd } \\
\text { fPublished May 2004. Accessed October } 2014 .\end{array}$ \\
\hline $\begin{array}{l}\text { University of Washington } \\
\text { (WA, United States) }\end{array}$ & $\begin{array}{l}\text { Julian KA, Monaghan C, Wamsley MA, Wipf JE, Zabar S. Residents-as- } \\
\text { teachers curricula: how to initiate, evaluate, and sustain. } 27^{\text {th }} \text { annual SGIM } \\
\text { Meeting. Society of General Internal Medicine. } \\
\text { http://impak.sgim.org/userfiles/file/AMHandouts/AM04/Workshops/WB08.pd } \\
\text { f Published May 2004. Accessed October 2014. }\end{array}$ \\
\hline
\end{tabular}




\begin{tabular}{|l|l|}
\hline $\begin{array}{l}\text { Workshop of US internal } \\
\text { medicine program directors }\end{array}$ & $\begin{array}{l}\text { Heflin MT, Pinheiro S, Kaminetzky CP, McNeill D. 'So you want to be a } \\
\text { clinician-educator...': designing a clinician-educator curriculum for internal } \\
\text { medicine residents. Med Teach. 2009 Jun;31(6):e233-40. }\end{array}$ \\
\hline
\end{tabular}

Table 3. CME curricula

\begin{tabular}{|l|l|}
\hline Institution/Organization & Citation of documents reviewed \\
\hline $\begin{array}{l}\text { Association of Professors of } \\
\text { Gynecology and Obstetrics } \\
\text { (Washington DC, United } \\
\text { States) }\end{array}$ & $\begin{array}{l}\text { Association of Professors of Gynecology and Obstetrics. 2010-2011 Academic } \\
\text { Scholars and Leaders Program [course syllabus]. 2010. }\end{array}$ \\
\hline $\begin{array}{l}\text { Beth Israel Deaconess Medical } \\
\text { Center } \\
\text { (MA, United States) }\end{array}$ & $\begin{array}{l}\text { Beth Israel Deaconess Medical Center. 2015 Maximizing Your Teaching Skills } \\
\text { CME [course syllabus]. 2015. }\end{array}$ \\
\hline $\begin{array}{l}\text { Beth Israel Deaconess Medical } \\
\text { Center } \\
\text { (MA, United States) }\end{array}$ & $\begin{array}{l}\text { Smith C, Newman L. Rabkin Fellowship in Medical Education Schedule 2013- } \\
4 \text { [course syllabus]. 2014. }\end{array}$ \\
& $\begin{array}{l}\text { Smith C, Newman L. Rabkin Fellowship in Medical Education Schedule 2014- } \\
5 \text { [course syllabus]. 2014. }\end{array}$ \\
\hline $\begin{array}{l}\text { Harvard Macy Institute } \\
\text { (MA, United States) }\end{array}$ & $\begin{array}{l}\text { Harvard Macy Institute. 2015 Program for Educators in Health Professions } \\
\text { January Calendar [course calendar]. 2015. }\end{array}$ \\
& $\begin{array}{l}\text { Harvard Macy Institute. 2015 Program for Educators in Health Professions } \\
\text { May Calendar [course calendar]. 2015. }\end{array}$ \\
\hline
\end{tabular}


Appendix 2: SaT Delphi Round One Survey Development. Twenty-eight unique content areas were identified from existing RaT, SaT, and CME curricula (listed in Appendix 1) and organized into eight thematic domains (bolded below).

\section{- Classroom instruction topics (4)}

○ Instructional design/pedagogical approaches (e.g. flipped classroom, problem-based learning, team-based learning)

- Lesson/curriculum planning (e.g. Kern's 6-step approach to curriculum development, writing learning goals/objectives)

- Small-group teaching (e.g. facilitating small-group discussions and didactic workshops)

- Large-group teaching (e.g. lecturing for large audiences)

\section{- Clinical instruction topics (4)}

○ Bedside teaching (e.g. how to teach small groups or individuals in the presence of a patient)

- Procedural and skills-based teaching (e.g. how to teach a clinical skill or procedure such as suturing, lumbar puncture, auscultating, etc.)

- Precepting in clinical contexts (e.g. how to employ "one-minute preceptor"/SNAPPS precepting models in inpatient and outpatient settings)

- Teaching patients (e.g. how to teach a patient about a medical diagnosis, shared-decision making)

- $\quad$ Feedback \& assessment topics (3)

- Feedback (e.g. providing effective formative and summative feedback to learners)

- Learner assessment in medical education (e.g. Miller's pyramid, ACGME competencies and milestones, OSCEs, creating MCQs)

- Working with "difficult learners" (e.g. how to address problematic teaching-learning encounters, remediation plans)

- Learning theory \& science topics (3)

- Adult and experiential learning theory (e.g. Kolb's cycle, andragogy)

- Cognitive science principles for teaching and learning (e.g. cognitive load theory, novice-expert shifts, transfer of learning)

○ Learning environment (e.g. role of emotion/context in learning, creating a safe learning environment)

- Modes of teaching topics (4) (modified in Round 2 to "Teaching strategies \& skills")

- Case-based teaching (e.g. teaching through a clinical case)

- High-fidelity simulation teaching (e.g. teaching through high-fidelity simulation exercises with a computerized manikin)

- Interprofessional teaching (e.g. teaching in outpatient and inpatient interprofessional settings)

- Teaching through arts \& the humanities (e.g. teaching about patient-doctor relationships/visual diagnosis skills through arts \& humanities)

- Reflective practice topics (3)

- Peer observation of teaching (e.g. observing/evaluating a peer's teaching)

- Metacognitive strategies for teaching \& learning (e.g. how to self-reflect on one's teaching and learning processes)

- Self-directed learning principles (e.g. how to engage in self-assessment, how to build self-directed learning plans)

- Scholarship \& leadership topics (3)

- Career development as a medical educator (e.g. how to build an educator's portfolio, mentorship) 
- Research in medical education (e.g. research questions, study designs, avenues for scholarship)

- Leading clinical teams (e.g. role modeling, conflict management, time management)

- Miscellaneous topics (4)

- The hidden/informal curriculum (e.g. behaviors that may convey messages about professional culture and values)

- Digital innovations in teaching and learning (e.g. social media, podcasts, mobile applications for teaching and learning)

- Professionalism as a medical educator (e.g. accountability, commitment to students, digital professionalism)

- Program evaluation (e.g. Kirkpatrick's pyramid, evaluation logic model) 